The PROWESS SHOCK Steering Committee

B. Taylor Thompson

V. Marco Ranieri

Simon Finfer

Philip S. Barie

Jean-Francois Dhainaut

Ivor S. Douglas

Bengt Gårdlund

John C. Marshall

Andrew Rhodes

\section{Statistical analysis plan of PROWESS SHOCK study}

Accepted: 6 July 2010

Published online: 6 August 2010

(C) Copyright jointly held by Springer and ESICM 2010

Electronic supplementary material

The online version of this article

(doi:10.1007/s00134-010-1977-3) contains supplementary material, which is available to authorized users.

Dear Editor,

The steering committee (SC) of the PROWESS SHOCK study has put in place processes that should guarantee independence and transparency to resolve the controversies surrounding the investigation and use of drotrecogin alfa (activated), thus serving the best interests of our patients [1].

The SC anticipated that the mortality rates from sepsis may be decreasing in response to improved quality of care [2] with a consequent influence on the sample size calculation for the PROWESS SHOCK study. We have described the impact of a falling placebo mortality rate and how the sample size would need to be changed to maintain $80 \%$ power to detect a $20 \%$ relative mortality reduction with drotrecogin alfa (activated) [2]. Accordingly, we employed a conditional power design to resize the study if aggregate mortality observed for the first 750 patients was lower than the anticipated $31.5 \%$ $[1,3]$.

Recent reports do indeed suggest temporal improvements in sepsis mortality. A multicenter demonstration project of a sepsis treatment "bundle" demonstrated a 5.4\% absolute decrease in hospital mortality in the 15,022 subjects treated between 2005 and 2008 [4]. The australian and new zealand intensive care (ANZIC) research network investigators demonstrated a reduction in hospital mortality from $35.6 \%$ to $21.2 \%$ $(n=7,250)$ over an 8-year period ending in 2005 [5]. Recent trials have also reported lower than expected mortality. An international trial of TAK-242, a TLR-4 antagonist, enrolled 274 patients from 94 medical centers with septic shock or sepsis requiring mechanical ventilation and noted a placebo 28-day mortality of $28 \%$ despite a sequential organ failure assessment (SOFA) score over 8 . The predicted mortality for sample size estimation was $40 \%$ [6]. A phase 2 trial of eritoran tetrasodium (E5564) enrolled adults with severe sepsis. The average predicted mortality was $53 \%$, yet the observed 28-day mortality was 24-25\% [7].

On 12 May 2010 the SC reviewed the aggregate baseline characteristics and 28-day mortality for the first 753 subjects in the PROWESS SHOCK study. At baseline, the mean number of organ failures was 3.5, all subjects were vasopressor dependent throughout the 17-h (mean) pre-enrollment period, $72 \%$ had renal dysfunction, and the (mean) total SOFA score was 9. The selected population therefore has a higher disease severity compared with PROWESS [8]. However, the aggregate mortality was $27.6 \%$. Accordingly, the SC approved a protocol-specified increase in sample size from 1,500 to 1,696 subjects (848 per group).

The analyses for the primary publication will be done by an independent academic statistical center [the Duke Clinical Research Institute (DCRI), Drs. Kerry Lee and Robert Califf]. Furthermore, the statistical analysis plan (SAP) has been developed in collaboration with the steering committee, the sponsor, and the DCRI, and the final plan submitted to the Food and Drug

Administration (FDA) in February of this year, prior to the first interim analysis by the data monitoring committee (DMC). Furthermore, and in accordance with recent calls for publication of analysis plans in advance of study completion, we are attaching the entire SAP as a supplement to this letter [9].

As of the end of June we have enrolled 971 subjects into the trial, with the majority being enrolled in Europe. Based on the current rate of enrollment and the assumption that the DMC will allow the study to continue to completion, we anticipate that the study will be completed in spring or summer 2011.

We wish to thank all our study subjects and their families, as well as our dedicated co-investigators and research coordinators and the sponsor, Eli Lilly, for their participation, support, and hard work on this important study.

\section{References}

1. Finfer S, Ranieri VM, Thompson BT, Barie PS, Dhainaut JF, Douglas IS, Gårdlund B, Marshall JC, Rhodes A (2008) Design, conduct, analysis and reporting of a multi-national placebocontrolled trial of activated protein $\mathrm{C}$ for persistent septic shock. Intensive Care Med 34:1935-1947

2. Dellinger RP, Levy MM, Carlet JM, Bion J, Parker MM, Jaeschke R, Reinhart $\mathrm{K}$, Angus DC, Brun-Buisson C, Beale R, Calandra T, Dhainaut JF, Gerlach H, Harvey M, Marini JJ, Marshall J, Ranieri M, Ramsay G, Sevransky J, Thompson BT, Townsend S, Vender JS, Zimmerman JL, Vincent JL (2008) Surviving sepsis campaign: international guidelines for management of severe sepsis and septic shock: 2008. Intensive Care Med 36:296-327 
3. http://www.fda.gov/downloads/Drugs/ Guidance Compliance Regulatory Information/Guidances/UCM201790.pdf

4. Levy MM, Dellinger RP, Townsend SR, Linde-Zwirble WT, Marshall JC, Bion J, Schorr C, Artigas A, Ramsay G, Beale R, Parker MM, Gerlach H, Reinhart K, Silva E, Harvey M, Regan S, Angus DC (2010) The surviving sepsis campaign: results of an international guidelinebased performance improvement program targeting severe sepsis. Intensive Care Med 36:222-231

5. Delaney A, Angus DC, Bellomo R, Cameron P, Cooper DJ, Finfer S, Harrison DA, Huang DT, Myburgh JA, Peake SL, Reade MC, Webb SA, Yealy DM, Resuscitation in Sepsis Evaluation (ARISE), Protocolized Care for Early Septic Shock (ProCESS) Investigators, Protocolised Management In Sepsis (ProMISe) Investigators (2008) Bench-to-bedside review: the evaluation of complex interventions in critical care. Crit Care $12: 210$

6. Bernard GR et al (2007) TAK-242 Treatment for severe sepsis: a randomized controlled trial. Crit Care Med 35:A264(946)

7. Tidswell M, Tillis W, Larosa SP, Lynn M, Wittek AE, Kao R, Wheeler J, Gogate J, Opal SM, Eritoran Sepsis Study Group (2010) Phase 2 trial of eritoran tetrasodium (E5564), a toll-like receptor 4 antagonist, in patients with severe sepsis. Crit Care Med 38:72-83
8. Bernard GR, Vincent JL, Laterre PF, LaRosa SP, Dhainaut JF, LopezRodriguez A, Steingrub JS, Garber GE, Helterbrand JD, Ely EW, Fisher CJ Jr, Recombinant human protein $\mathrm{C}$

Worldwide evaluation in severe sepsis (PROWESS) study group (2001) Efficacy and safety of recombinant human activated protein $\mathrm{C}$ for severe sepsis [comment]. N Engl J Med 344:699-709

9. Finfer S, Bellomo R (2009) Why publish statistical analysis plans? Crit Care Resusc 11:5-6

B. T. Thompson

Pulmonary and Critical Care Unit, Massachusetts General Hospital,

Boston, MA, USA

V. M. Ranieri ( $\square)$

Ospedale S. Giovanni Battista-Molinette,

Università di Torino, Turin, Italy

e-mail: marco.ranieri@unito.it

S. Finfer

The George Institute for International

Health, University of Sydney,

Sydney, Australia
P. S. Barie

Department of Surgery, P713A Weill

Cornell Medical College, New York,

NY 10065, USA

J.-F. Dhainaut

Cochin Port-Royal University, Paris, France

I. S. Douglas

Denver Health and University of Colorado, Denver, CO, USA

B. Gårdlund

Department of Infectious Diseases, Karolinska University Hospital, 14186 Stockholm, Sweden

J. C. Marshall

Department of Surgery and Critical Care Medicine, St. Michael's Hospital,

Toronto, ON M5B 1W8, Canada

\section{A. Rhodes}

Department of Intensive Care Medicine and Anaesthesia, St. George's Hospital, London, UK 